\title{
A Review on the Pharmacology of Holostemma ada-kodien - A Vulnerable Medicinal Plant
}

\author{
Siddharuda Tuppad $^{1 *}$, G. Raviraja Shetty ${ }^{1}$, Laxmi Mastiholi ${ }^{1}$, M.S. Sandesh ${ }^{1}$, \\ K. Souravi ${ }^{2}$ and P.E. Rajasekharan ${ }^{2}$ \\ ${ }^{1}$ Department of Plantation, Spices, Medicinal and Aromatic Crops, College of Horticulture, \\ Mudigere-577132, University of Agricultural and Horticultural Sciences, \\ Shivamogga, Karnataka, India \\ ${ }^{2}$ Division of Plant Genetic Resources, ICAR- IIHR, Bengaluru, Karnataka, India \\ *Corresponding author
}

\begin{tabular}{|c|c|}
\hline & A B S T R A C T \\
\hline Keywords & Holostemma ada-kodien is a vulnerable medicinal species belongs to \\
\hline $\begin{array}{l}\text { Holostemma ada- } \\
\text { kodien, Vulnerable } \\
\text { species, Medicinal } \\
\text { uses, Pharmacological } \\
\text { activity. }\end{array}$ & $\begin{array}{l}\text { contain numerous medicinal properties and is of very high commercial } \\
\text { value. The tuberous roots of } H \text {. ada-kodien are used in herbal formulas. It } \\
\text { contains the terpenoid sugar which has been studied for its various }\end{array}$ \\
\hline Article Info & medicinal activities such as antipyretic, antioxidant, antidiabetic, \\
\hline $\begin{array}{l}\text { Accepted: } \\
\text { 12 September } 2017 \\
\text { Available Online: } \\
10 \text { November } 2017\end{array}$ & $\begin{array}{l}\text { hepatoprotective, antibacterial, and anthelmintic activity. This review is a } \\
\text { comprehensive overview about the existing pharmacology of } H \text {. ada- } \\
\text { kodien, helping to fuel further research in the various unexplored activities } \\
\text { that are attributable to this plant. }\end{array}$ \\
\hline
\end{tabular}

\section{Introduction}

Since time immemorial, mankind has searched for medicines to remove pain and cure various diseases. Evidence exists for the use of medicinal plants up to 60,000 years ago but more recently, a 5000-year-old Sumerian clay slab was discovered verifying the utilization of medicinal plants for the preparation of drugs (Summer, 2000). Plants have different chemical compounds like secondary metabolites with many biochemical and bioactivity properties showing applications in various industries such as pharmaceuticals (Koly Aktar and Tahira Foyzun, 2017). The interest in using natural sources or green medicine or medicinal plants is increasing worldwide due to their safety, efficacy, cultural acceptability, and lesser side effects as compared to synthetic drugs. One such medicinal plant is the $H$. ada-kodien, whose mention has been found since the ancient times, in the form of the drug "jivanthi" (Kolammal, 1979). Which has been an important ingredient in a number of ayurvedic formulations. $H$. ada-kodien yields 
terpenoid sugars, and other highly valued secondary metabolites, which have a wide range of clinical applications such as antipyretic, antioxidant, antidiabetic, hepatoprotective, antibacterial, and anthelmintic activity etc.

\section{Taxonomic classification (Albers, 1976)}

Kingdom: Plantae, Phylum: Magnoliophyta, Class: Magnoliopsida, Order: Gentianales, Family: Asclepiadaceae, Genus: Holostemma and Species: Holostemma ada-kodien

Several vernacular names of Holostemma ada-kodien in different languages, in Sanskrit, it is known as Jivanti; Arane beeru, Jeeva haale, Maruligana kasa in Kannada; Holostemma in English; Chirvel, Kanju in Hindi and Adapathian, Atapatiyan in Malayalam (Joy et al., 1998).

\section{Plant description}

Holostemma ada-kodien is a laticiferous perennial climber (Sivarajan and Balachandran, 1994; Kirtikar and Basu, 1975; Irimpan et al., 2011) with slightly reddish stem. Immature leafs are light green were as mature ones are dark green in color. Leaf texture varied from smooth to slightly rough. The leaf shape was found to be ovate, slightly cordate and oblong.

Leaf apex shape varied from acute cuspidate and leaf base shape auriculate. Leaf venations are distinct with green and purplish colour and absence of leaf waxiness. Petiole color is green. Inflorescence is axillary cyme, flower bud is globose shape have medium to large. Corolla is gamopetalous, three colored type flowers viz., creamish white, creamish white with pink streaks and pinkish.

\section{Ecology}

The peak flowering season during June to November, the fruits start to drying JanuaryFebruary month. Fruit maturation takes 102 to 158 days and seeds are very small, flat and dark brown in color, an healthy fruit contains 300-350 seeds and the tuberous roots are ready for harvesting after one and-a-half years.

\section{Reasons for vulnerable}

Although widely distributed throughout Southern India, the population in wild is gradually reducing due to the destructive and ruthless collection of root tubers, as a raw material for the ayurvedic drug preparations, and fruit set is a major problem in multiplying the species in wild, and other anthropogenic reasons the species became vulnerable (Nair et al., 1992).

\section{Chemical composition}

Root tubers contain the terpenoid sugars which have medicinal properties (Ramaiah et al., 1981). Its roots contain moisture $10.8 \%$, Protein $4.07 \%$, Sugar 24\%, Starch $32.54 \%$, Fiber $12.2 \%$, ash $3.07 \%$ ash contained $\mathrm{Ca}$ and P $2.50 \%$ ethanol extract of roots contained six amino acids viz., alanine, glycine, serine, aspartic acid, threonine and valine, and benzene extract contained $\alpha$-amyrin, lypeol and $\beta$-sitosterol (Manikpuri et al., 2010).

\section{Propagation}

The species is propagated through seeds. Matured seeds are collected from the plant during January-February before they disperse from fruit. Seeds are cleaned, dried, and stored for sowing. But fruit set is usually less than $10 \%$ in this species, which is a major constraint for large-scale cultivation through seeds. The crop can also be propagated by 
vegetative means through root and stem cuttings (Anita, D., 2008).

\section{Medicinal uses}

Traditionally the plant is used as an alternative, astringent to the bowels; cures ulcers, diseases of the blood, itching, leucoderma, gonorrhea and it has ability to maintaining vigour, strength and vitality (Kirtikar, 1993; Gamble, 1967; Meena Thomas Irimpan, 2011). The root and leaves are used in the form of powder and juice to treat spider-poisoning. The roots rubbed into a mash are used in cold milk as a curare to diabetes (Kirtikar and Basu, 1975).

The tuberous roots are useful in rejuvenative, aphrodisiac, expectorant, intestinal disorders galactogogue, stimulant, orchitis, pain, stomach ache, and in ophthalmic disorders (Singh et al., 2012; Warrier, et al., 1995; Chopra, et al., 1956). And it has also some proven medicinal activity viz., anti-diabetic (Janapati et al., 2009) antipyretic, anthelmintic (Rubesh kumar Sadasivam et al., 2014), antioxidant (Mallikarjuna et al., 2011), hepatoprotective (Junapudi Sunil et al., 2015) activity. Besides the medicinal virtues, the leaves, flowers and fruits are eaten as vegetables. And its bark fibre reported to be suitable for cordage and paper making.

\section{Pharmacological potential}

\section{Antipyretic activity}

This study was carried out to evaluate the antipyretic activity of the leaf extracts of $H$. ada-kodien. The methanolic and ethyl acetate leaf extract at the rate of 200 and $400 \mathrm{mg} / \mathrm{kg}$ was compared against the acetylsalicylic acid $(300 \mathrm{mg} / \mathrm{kg})$ and acetylsalicylic acid as positive control for assessing antipyretic activity on wistar rats. The methanolic showed the dose dependence reduction in hyperpyrexia when compared with the ethyl acetated extract and positive control. Hence further investigation on the isolation of active principle will lead to a potent anti-pyretic agent (Rubesh kumar sadasivam et al., 2014)

\section{Antioxidant activity}

This study was carried out to evaluate antioxidant activity of hexane, ethyl acetate and methanolic extracts of $H$. ada kodien root tubers. The above extracts exhibited a dose dependent scavenging activity against 2, 2'diphenly-1-picrylhydrazyl (DPPH) radicals, Superoxide radicals, and Nitric oxide radicals. Further, the methanolic and ethanolic extracts showed relatively higher reducing power compare to that of butylated hydroxytoluene. TLC of the above extracts using the DPPH as a spraying reagent revealed yellow spots against purple background indicating the presence of potent antioxidant compounds (Mallikarjuna et al.,2011).

\section{Anti-Diabetic Activity}

Evaluation was done to study the antidiabetic activity and phytochemical studies of ethanolic extract of Holostemma ada kodien in normal, glucose fed, alloxan-induced diabetic rats and to perform phytochemical studies. The alcoholic extract of $H$. ada kodien was studied for antidiabetic activity in normal, glucose fed and alloxan- induced diabetic rats by oral administration of extract (200 and $400 \mathrm{mg} / \mathrm{kg}$ body wt) for 7 days. The effect was compared with $0.5 \mathrm{mg} / \mathrm{kg}$ (i.p) glibenclamide. The alcoholic extract significantly lowered the blood sugar of hyperglycemic rats. From phytochemical studies shows the presence of alkaloids, flavonoids, flavanones, tannins, terpenoids, amino acids and carbohydrates. The results revealed that the traditional use in the treatment of diabetes (Rubesh Kumar Sadasivam et al., 2014). 
Plate.1 Jeevanti (Holostemma ada-kodien) a. young plant b. flowers c. fruit d. seeds
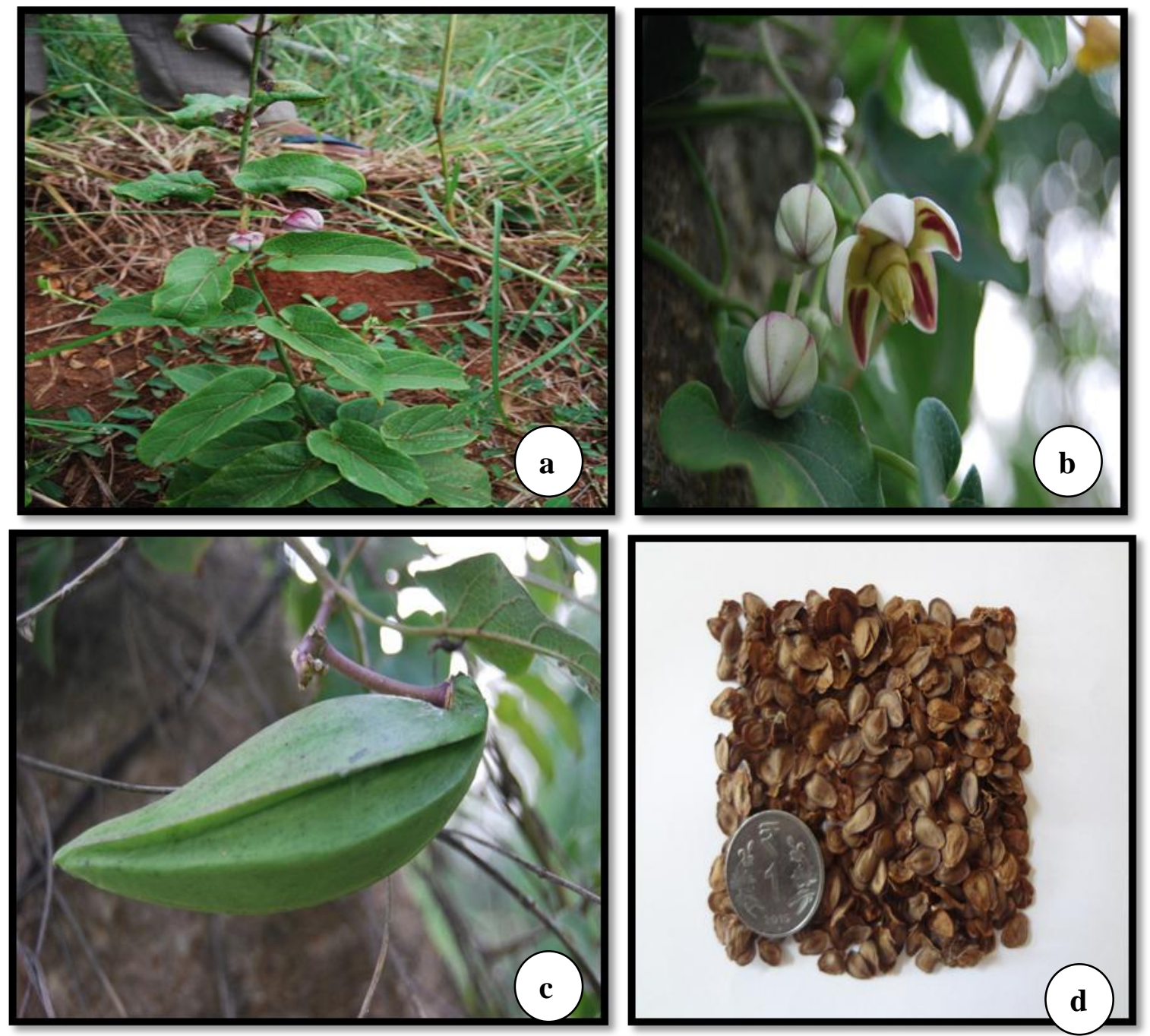

\section{Hepatoprotective activity}

Junapudi Sunil et al., (2015) studied on Hepatoprotective Activity of $H$. ada kodien they found that Pre-treatment of the rats with alcoholic extract prior to paracetamol (PCM) administration caused a significant reduction in the values of aspartate amino transferase (AST), alanine amino transferase (ALT), alkaline phosphatase (ALP) and serum bilirubin (SB) $\quad(p<0.01) \quad$ approximately comparable to the hepatoprotective of standard drug was silymarin. From this study showed that the alcoholic extract of $H$. ada kodien possesses the hepatoprotective effect against paracetamol (PCM) induced liver damage in rats.

\section{Antibacterial activity}

Meena Thomas Irimpan et al., 2011 reported the antibacterial activity of the traditionally used medicinal plant $H$. ada kodien (Asclepiadaceae), in both methanolic and aqueous leaf extracts, have gram positive and gram negative bacteria.

The plant extracts exhibited significant antimicrobial potency, comparable to standard antibiotic Gentamycin. 


\section{Anthelmintic activity}

This study was carried out to evaluate in-vitro anthelmintic activity of ethyl acetate leaf extracts of $H$. ada-kodien on Indian earthworm (Pheretima posthuma) for the various concentrations ranging from 50, 100, 200 and $400 \mu \mathrm{g} / \mathrm{ml}$. Albendazole was used as standard reference and distilled water as control. The paralytic and death rate were found to be exhibits the anthelmintic activity in its leaf extract (Rubesh Kumar Sadasivam et al., 2014)

\section{Ethnogynaecological study}

Abdulla Naseef et al., (2012), recorded the ethnogynaecological plants in the Paniya tribe. In their, Holostemma tubers (Holostemma ada-kodien) are boiled and taken as breakfast for gynaecological ailment.

In the present review, we have tried to summarize about Phytochemistry, Pharmacological activities of $H$. ada-kodien Schult. The plant contains of flavonoids; tannins, saponines, anthocyanins, steroids, alkaloids and phenols. There is no report regarding isolation of single chemical compounds and secondary metabolites. In review reported antipyretic, antioxidant, antidiabetic, hepatoprotective, antibacterial, and anthelmintic activity of $H$. ada-kodien.

\section{References}

Abdulla Naseef, S.A., Ajesh, T. P., and Kumuthakalavalli, R., 2012, study on folklore medicinal practices of Paniya tribes for gynaecological ailments. Int J Pharm Bio Sci 2012 3(4): 493 - 501.

Albers, F., 1976, Chromosome numbers in the Stapelieae (Asclepiadaceae). In: IOPB Chromosome number reports LI (A. Love). Taxon; 25:155-164.
Anita, D., 2008, Agro-techniques of selected medicinal plants, National Medicinal Plants Board, Department of AYUSH, Ministry of Health and Family Welfare, Government of India. pp. 103-106.

Chppr, R.N., Nayar, S.L., and Chopra, I.C., 1956, Glossary of Indian Medicinal plant, Council of scientific andd\& industrial research., pp.135-145.

Frlht., 1997, Medicinal plants of IndiaGuidelines for national policy and conservation programs (Foundation for Revitalization of Local Health Traditions, Bengaluru (India).

Gamble, J.S., 1967, Flora of the presidency of madras, 2nd edition. Botanical Survey of India, India, pp. 1286.

Janapati, Y., Ahmad, R., Jayaveera, K. and reddy, R., 2009, Hypoglycemic and antidiabetic activity of alcoholic extract of Holostemma adakodien in alloxan induced diabetic rats. The Int. J. Endocrinology, 5(2): 1-5.

Joy, P., Thomas, J., Mathew, S. and Skaria, P.B., 1998, Medicinal Plants, Kerala Agricultural University. Aromatic and Medicinal Plants Research Station.

Junapudi Sunil, Janapati, Y., Yasodha, K., Pallaval, V., Bramhachari., 2015, Hepatoprotective Activity of Holostemma ada-kodien shcult, Extract against Paracetamol Induced Hepatic Damage in Rats. European Journal of Medicinal Plants 6(1): 45-54.

Kirtikar, K.R. and Basu, B.D., 1975, Indian Medicinal Plants. M/ s Bishen Sigh Mahen drapal, New Delhi, India, pp. 162.

Kirtikar, K.R., 1993, Indian medicinal plants 2nd ed. Periodical Experts Book Agency; India. 2: 894-895.

Kolammal, M. (1979): Pharmacognosy of Ayurvedic Drugs, Kerala, Trivandrum.

Koly Aktar, and Tahira Foyzun., 2017, Phytochemistry and Pharmacological Studies of Citrus macroptera: A 
Medicinal Plant Review, Hindawi Evidence-Based Complementary and Alternative Medicine. 7: 1-7.

Mallikarjuna, B., Usha, N.R., Gayathri, D. and Ramagopal, G., 2011, In-vitro antioxidant and free radical scavenging potential of Holostemma ada-kodienAn Important Rare Medicinal Plant. Int J Pharmaceutical sci \& res, 2(9): 24132418.

Manikpuri, N., Jain, S.K. and Manoj, K., 2010, Phytochemical investigation of bioactive constituent of some medicinal plants. Intl Research Journal, 2(13): 3738.

Meena Thomas Irimpan., Jolly, C.I., Sheel, A.D., 2011, A study of the phytochemical composition and antibacterial activity of Holostemma ada-kodien. Int. J. Pharm Tech Res, 3(2): 1208-1210.

Nair, K.V., Nair, A.R. and Nair, C. P., 1992, Technoeconomic data on cultivation, preservation of some south Indian medicinal plants. Aryavaidyan 5: 238240.

Ramaiah, N., Nair, G.A. and Prasad, N.B., 1981, Chemical components of Holostemma annulare K. Schum. J. Sci Res, 2: 76-78.
Rubesh Kumar Sadasivam., Sridhar, C. and Jayaveera, K.N., 2014, Antipyretic activity of methanolic and ethyl acetate extract of Holostemma ada kodien on wistar rats. Int. J. Pharmacognosy and Phytochemical Res, 6(2): 335-338.

Rubesh Kumar Sadasivam., Sridhar, C. and Jayaveera, K.N., 2014, In-Vitro Anthelmintic Activity Of Leaf Extracts Of Shorea tumbuggaia Roxb. Andholostemma ada kodien Schult. On (Pheretima Posthuma) Indian Earthworm. Asian J Pharm Clin Res, 7(12): 95-97.

Singh, R., Sarabjeet, S., Jeyabalan, G. and Ashraf, A., 2012, An overview on traditional medicinal plants as aphrodisiac agent. Journal of Pharmacognosy and Phytochemistry, 1: 43-55.

Sivarajan, V.V. and Balachandran, I., 1994, Ayurvedic drugs and their plant sources. 195th ed, Oxford and IBM Pub Co Pvt Lt: New Delhi, pp. 374-376.

Summer, J., 2000. The Natural History of Medicinal Plants, vol. 16, Timber Press, London, UK

Warries, P.K., Nambiar, V.P., and Raman, K.C., 1995, Indian medicinal plants: A compendium of 500 species. Orient Longman 3:165.

\section{How to cite this article:}

Siddharuda Tuppad, G. Raviraja Shetty, Laxmi Mastiholi, M.S. Sandesh, K. Souravi and Rajasekharan, P.E. 2017. A Review on the Pharmacology of Holostemma ada-kodien - A Vulnerable Medicinal Plant. Int.J.Curr.Microbiol.App.Sci. 6(11): 1532-1537. doi: https://doi.org/10.20546/ijcmas.2017.611.181 